\title{
The transposition of a Philosophy subject matter. C.S. Peirce as 'knowledge to be taught'
}

\author{
Laura Sara Agrati \\ Università Telematica "Giustino Fortunato"
}

How to cite this paper: Agrati, L. S. (2019). The transposition of a Philosophy subject matter. C.S. Peirce as 'knowledge to be taught'. The Educational Review, USA, 3(12), 220-234.

\section{http://dx.doi.org/10.26855/er.2019.12.004}

*Corresponding author: Laura Sara Agrati, Università Telematica "Giustino Fortunato".

E-mail: laurasara.agrati@gmail.com

\begin{abstract}
The school mediation acts as 'integration' (Chocran, 1997) of a subject matter: it transforms cultural objects and produces new knowledge. Referring to the theoretical model of PCK (Pedagogical Content Knowledge - Shulman, 1986, 1987), of 'Didactic transposition' (Chevallard, 1991; Develay, 1992, 2015; Waquet, 2015) and to a previous study addressing the process of integration of a Philosophy subject matter (G.B. Vico, Agrati, 2019), this study was conducted on the I phase of transposition that is made by the editors and authors of textbook through the contents selected (Kang \& Kilpatric, 1992; Clement, 2007; Vaz, 2017).

The paper presents further results of a second exploratory study aimed at detect the main topics of C.S. Peirce, found in textbooks and how these have been made explicit by the texts/graphic organizers. The textbook analysis $\left(\mathrm{O}^{\prime}\right.$ Keeffe, 2013; Chiappetta et al., 1993) was carried out through a comparison of textual-graphic devices used by two philosophy textbooks: it was conducted on the index of the entire textbook and on the sections related to the American philosopher and it used 'ad hoc' analysis criteria - content (selection of topics and prevailing links), structure (sequence and articulation of topics within the whole work) and language (meaning of terms and technical vocabulary) (Valverde at al., 2002; Rivers, 1990).

The findings are about the contents' modification - more extended or more reduced compared to the main topics (v. belief, abduction, semiotics) - and the topics' explication (v. neologisms and metaphors); they confirm and make explicit the work of transformation made by the textbooks' authors which elaborate a 'knowledge to teach' (Develay, 2015) different than the 'scholarly knowledge' and that could condition the teaching process and the student's learnings.
\end{abstract}

\section{Keywords}

didactic mediation, $\mathrm{PCK}$, transposition

\section{Introduction. The Whole Process of School Mediation}

From the educational point of view and according to the constructivist perspective, the whole process of mediation concerns, on one hand, the relation (Vygotsky, 1934) of a child with the reality on perceptive and cognitive levels and, on other, the more or less explicit process of socialization that takes place first of all in the family (Levi-Strauss, 1949; Damiano, 2013) then at school (Benadusi, Censi, Fabretti, 2004) and that provide children with cultural tools and social rules in order to become adult.

Regarding the school teaching and according the socio-constructivist perspective (Altet, 1997), the mediation process refers to all strategies that the school uses to promote student learning (Damiano, 2013; Xipas, Fabre, Hétier, 2011), 
at relational and cognitive level. A specific aspect of this process is that of 'integration' (Cochran, 1997) that involves teachers $(\mathrm{T})$ when they relate students $(\mathrm{S})$ and cultural object $(\mathrm{Co})$, trough a system of devices $(\mathrm{Md})$ (figure 1). For example, a Philosophy teacher (T) teaches 'Hegel', a school content of the syllabus of Philosophy (Co), in a High School V class (St) through a lesson (Md1), in which he/she argues the contents of the textbook, or through a research laboratory $(\mathrm{Md} 2)$ that directly involves the students in examining one or more works by the great philosopher of Idealism.

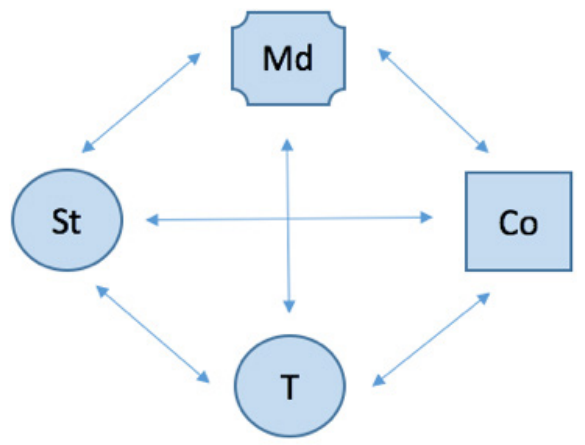

Fig. 1: School mediation process -Adapt.: Damiano, 2013, in Agrati (2019).

As shown in the fig.1, the process of mediation - as 'integration' - is characterized by mutual relations (Damiano, 2013, p. 76) of each item (teacher, student, mediation devices, cultural objects). The double directional arrows meant that: a. teachers and students modify mediation devices, $b$. themselves are modified by the use of mediator devices- e.ga lesson has a different impact on the involvement of the teachers and on the learnings of the students compared to an active research.

Seen within the model of school mediation as 'integration' (fig. 1), the cultural object (Co) would also seem to be influenced by the teachers, students and mediation devices (degree of proficiency of the teacher, of interest and prior knowledge of the students, of explication offered by the devices with respect to, for example, specific contents). However, this model is useful to explain only one phase of the mediation process ('integration' that takes place at school), does not clarify an earlier phase, which concerns the production process of the cultural object and for which the 'didactic transposition' (Chevallard, 1991; Develay, 1992, 2015; Waquet, 2015) would be theoretically and methodologically more useful.

\section{Theoretical Framework}

The socio-constructivist perspective highlights that the school - understood as an 'education system' that precisely involves the political-institutional and organizational teaching plan - has interest in providing students with useful knowledge and skills to become not only adults but also good citizens able to read the complexity of today's reality (UNESCO, 2015, 2017; Jerom \& Lalor, 2018).

School policies at the international level offer syllabi of knowledge and skills for the training of citizens that, at the national and territorial level, are integrated on the one hand in curricula and more or less compulsory school programs and downstream through the choice of textbook contents, in consistency with the programs. This level of mediation, less explored but preceding, is well highlighted by educational research within the construct of 'didactic transposition' which thus complements the explanatory central model of the PCK (Shulman, 1986, 1987; Ball, Thames, Phelps, 2008) of cognitive and disciplinary derivation.

\subsection{Pedagogical content knowledge}

The Pedagogical Content Knowledge (PCK) model of Shulman (1986) is useful as a reading/analysis tool of the mediation process because it clarifies the concept of 'content knowledge' ${ }^{1}$ and, in it, distinguishes among:

1) Subject matter content knowledge: different structures of content knowledge that refers to concepts and specific

\footnotetext{
${ }^{1}$ 'The amount and organization of knowledge itself (is) in the mind of the teacher' (Shulman, 1986, p. 7).
} 
domains (as Schwab's 'discipline' - 1978);

2) Pedagogical content knowledge: subject matter content knowledge for teaching ${ }^{2}$, such as 'the forms of representation of ideas, the most powerful analogies, illustrations, examples, explanations (...) the way of representing and formulating the subject that make it comprehensible to others' (Shulman, 1986, p. 9);

3) Curricular knowledge: 'the full range of programs for teaching of particular subject and topics at a given level' (p. 10) - as 'materia'.

The PCK has been defined as a 'type of knowledge that is unique to teachers, and is based on the manner in which the teachers relate their pedagogical knowledge (what they know about teaching) to their subject matter knowledge (what they know about what they teach)' (Cochran, 1997, p. 13): the 'integration' of teachers' pedagogical knowledge and their subject matter knowledge that comprises pedagogical content knowledge. Cochran (1997) highlights the 'personal representation' inherent the construct of 'pedagogical content knowledge' that differentiates the teacher from the scholar: 'pedagogical content knowledge is a form of knowledge that makes science teachers teachers (...). Teachers differ from scientists, not necessarily in the quality or quantity of their subject matter knowledge, but in how that knowledge is organized and used' (Cochran, 1997, p. 78).

\subsection{The process of didactic transposition}

The whole process of school mediation is theoretically explainable with the model of 'didactic transposition' that allows to easily represent, even to 'visualize' (fig. 2), the complex process that undergoes any kind of 'knowledge' in becoming a 'knowledge to be taught' and to clarify the responsibility of the actors participating the process, at least on two levels: the first external transposition leads to the definition of the curriculum of each school discipline (savoir à enseigner) and the second internal transposition is what makes this first knowledge the one actually taught (savoir enseignèe) and that each teacher produces in his/her classes according to pupils and the constraints (time, examinations, conformity to established school curriculum etc.).

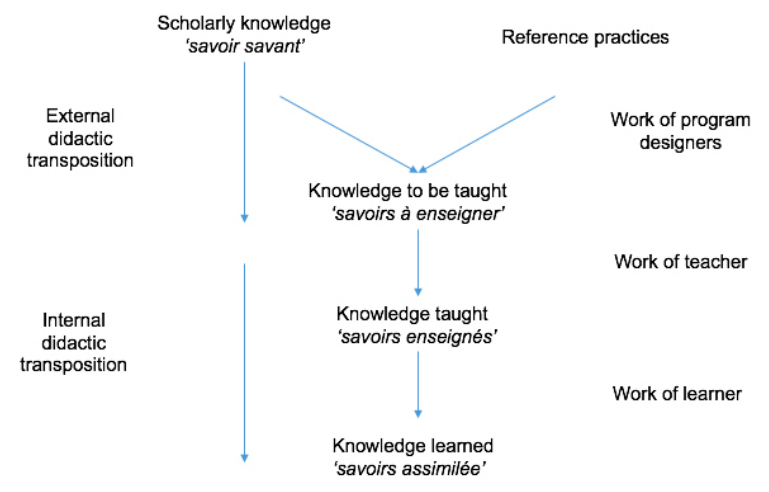

Fig . 2 - Scheme of Didactic transposition (Develay, 2015, p. 19)

Responsibility to knowledge. The model of didactic transposition defines the first level as savoir savant ('scholarly knowledge'), the set of knowledge historically and conventionally considered regarding a field/sector of study. The PCK model, on the other hand, uses the less formal term of 'knowledge', meaning the wealth of knowledge firmly accepted by the community of experts (i.e. the 'Philosophy' of accredited philosophy scholars) and which becomes the object of teaching (the 'Philosophy' to be taught at school) and to learn (the 'Philosophy' learned by students).

Although every kind of knowledge can be subjected to personal and community scrutiny and the freedom of teaching is to be defended, as in many countries around the world, the ethical responsibility of teachers in relation to knowledge implies commitment to respect, not to misrepresent, not to disavow and betray the knowledge - in other words, it is not correct to affirm that Hegel is not an idealist.

Responsibility to teaching content. The model of didactic transposition calls this second level as savoir à enseigner ('knowledge to be taught'), result of the inter-institutional agreement that involves the designers of school programs (Damiano, 2007, p.58), that is the common reference for the school curriculumand the didactic interventions and the

\footnotetext{
${ }^{2}$ As Shulman (1986), it refers to teachability but not to other elements as classroom organization and management, even though 'terribly important' (p. 14).
} 
editing of school textbooks and any types of didactical tools. This implies - as in Italy (CM 30/12/2010 m. 101; DM $22 / 07 / 2007$ ) - that every teacher can decide to integrate parts of the school curriculum or teaching resources (e.g. school textbooks) but must still ensure the contents of knowledge, considered essential for the education of students - as far as it is possible to teach or not M. Stirner, a member of the Left Hegelianism, it is necessary in any case to teach Hegel.

The didactic transposition model (fig. 2) also helps: a. to explain some aspects of the PCK model such as the distinction between subject matter content knowledge (Philosophy as science 'discipline', Schwab, 1978) and curricular knowledge (Philosophy as 'school subject', Shulman, 1986); b. to focus the difference between 'scientific knowledge' (produced by scholars and researchers - savoir savant) and 'knowledge to be taught' (developed by the designers of school programs and by the authors of school books - savoir à enseigner).

After a brief presentation of the Italian school syllabus of Philosophy (DPR 89/2010), the concepts of savoir savant and savoir à enseigner - on the example of Philosophical subject matter, the philosopher C.S. Perice - are explained.

\section{The Syllabus of Philosophy in Italy}

Philosophy is considered today as a cognitive-affective-social school subject, useful for the construction of the critical mind (UNESCO, 2007) and the civic skills of adolescents; in the past (Morgan \& Perry, 1957) it has instead been interpreted more according to a historical and centered-authors approach. Although absent in many school curricula (UNESCO, 2007, 2011), in the world there is a slow re-examination of the study of Philosophy, also thanks to interdisciplinary and intercultural paths (Haynes, 2016; Ferrari, 2017).

As a result of Presidential Decree no. 89/2010 the Philosophy as 'school subject' (Shulman, 1986) is taught in Italy in the III, IV and V year of high schools - artistic, classical, human sciences, linguistic, musical-dance and scientific. Although the syllabus follows a criterion of historical-historiographical organization for specific learning objectives $\left(3^{\text {rd }}\right.$ year from the origins to the $13^{\text {th }}$ century, $4^{\text {th }}$ year from Humanism to the Illuminism, $5^{\text {th }}$ year from Idealism to nowadays - see Tab. 1), there are thematic inserts such as political economy or arts, especially in the $3^{\text {rd }}$ year.

Tab. 1 - Contents and structure of the Syllabus of Philosophy in Italy (DPR n. 89/2010)

\begin{tabular}{|c|c|c|}
\hline Period & Contents & Value \\
\hline \multirow[t]{2}{*}{$19^{\text {th }}$ century thought } & $\begin{array}{l}\text { 'Schopenhauer, Kierkegaard, Marx, framed in the context of } \\
\text { reactions to Hegelianism, and of Nietzsche' }\end{array}$ & Compulsory content \\
\hline & $\begin{array}{l}\text { 'The cultural framework of the era }(\ldots) \text { examination of Positivism } \\
\text { and the various reactions and discussions it raises, as well as of } \\
\text { the most significant developments in the sciences and theories of } \\
\text { knowledge' }\end{array}$ & Content to completion \\
\hline $20^{\text {th }}$ century philosophy & $\begin{array}{l}\text { Four authors/problems from the following: } \\
\text { a) Husserl and phenomenology; b) Freud and psychoanalysis; } \\
\text { c) Heidegger and existentialism; d) Italian neoidealism e) } \\
\text { Wittgenstein and analytic philosophy; f) vitalism and pragmatism; } \\
\text { g) philosophy of Christian inspiration and the new theology; } \\
\text { h) interpretations and developments of Marxism, in particular } \\
\text { in Italy; i) themes and problems of political philosophy; l) } \\
\text { developments of epistemological reflection; i) philosophy of } \\
\text { language; l) philosophical hermeneutics. }\end{array}$ & Content by choice \\
\hline
\end{tabular}

\section{C.S. Peirce as 'savoir savant' and 'savoir à enseigner'}

'Teaching someone else's thought is a dark art. When that person's thought is as extensive, difficult, and developmental as that of Charles Peirce, the art is even darker' (Anderson, 2007, p. 27). Anderson's quote expresses the complexity of Peirce's thought and teaching. The American mathematician and philosopher Charles Sanders Peirce (1839-1914) is known mainly for his contributions in the logical, epistemological and semiotic fields ${ }^{3}$. The main topics of Peirce's

\footnotetext{
${ }^{3}$ Logic-semiotic and pragmatic works: Some Consequences of Four Incapacities (1868), The Fixation of Belief (1877), How to Make Our Ideas Clear (1878), What Pragmatism Is (1905), Issues of Pragmaticism (1905). Metaphysical works: The Doctrine of Necessity Examined (1892), The Categories and the Study of Signs (1904-6), A Neglected Argument for the Reality of God (1908).
} 
thought are considered (Bonfantini, 2003):

a. the pragmatic maxim according to which the conception that one person has of a thing corresponds to the practical consequences that person has experienced (Peirce, 1878) - 'Consider what effects, that might conceivably have practical bearings, we conceive the object of our conception to have. Then, our conception of these effects is the whole of our conception of the object' (Peirce, 1931-58,n. 5.2) - an aspect that defines as pragmaticism and not pragmatism his thought, as that of his friend and pupil W. James;

b. the Theory of sign extended to any process of signification ('semiosis'), which consists in deriving a meaning from a sign on the baseof a triadic relationship between sign, object, interpreting with a strong cognitive and not only communicative value - an aspect today particularly debated by the modern semiotic sciences (Bergman, 2004), above all regarding the distinction between the three categories of sign - index, icon and symbol - in the Media Education (Johansen \& Larsen, 2002): icon has a physical resemblance to the meaning, the thing is represented (photography as a direct representation of the object); index shows the evidence of what is represented (i.e., smoke that indicates the fire); symbol does not detect any direct similarity between signifier and meaning that must be learned culturally (i.e. numbers and letters of the alphabet).

c. the deepening of abductive reasoning, distinct with respect to other logical inferences - induction and deduction considered as the only form of reasoning capable of affectively increasing knowledge through hypothesis elaboration, the act of guessing and of predicting (see Tab. 2).

Tab. 2 - Three types of logical inferences. Adapt: Peirce, 2003, p. 460.

$\begin{array}{llll}\text { Definition } & \begin{array}{l}\text { Deduction: application of general } \\ \text { rules to particular cases }\end{array} & \begin{array}{l}\text { Induction: the inference of a rule } \\ \text { from a case and a result }\end{array} & \begin{array}{l}\text { Hypothesis: inference of a } \\ \text { case from a rule and a result } \\ \text { (abduction) }\end{array}\end{array}$
Exemplum
$\mathrm{R}$ : all the beans that come from this
$\mathrm{C}$ : these beans come from this bag
R: rule bag are white
$\mathrm{C}$ : these beans come from this bag
A: answer
A: these beans are white
A: these beans are white
$\mathrm{R}$ : all the beans that come from this bag are white
$\mathrm{R}$ : all the beans that come from this bag are white
A: these beans are white
$\mathrm{C}$ : these beans come from this bag

In Peirce the concept of 'semiosis' deserves a focus. It assumes a very broad and complex meaning: the way in which a person relates to reality (Maddalena, 2015), as well as how the mind is organized (Fadda 2013). In a work of 1867 the philosopher stated jet that 'the objects of the intellect, considered as representations, are symbols' (W2: 56) and, in his latest production, he came to identify the entire Logic and the semiotic, on a metaphysical (Peirce, 2003). Precisely because theoretically difficult to understand ${ }^{4}$, Peirce's meaning of semiotics has been subjected to simplification processes over the time. Scholars highlighted specific communication aspects (Ogden \& Richards, 1966; Manetti, 1987; Eco, 1984) about the entire process of signification related to sign, object and referent and crystallized it in the so called 'semiotic triangle' basic-scheme (Simmons, 2012) which then has become a canonical form of representation, in several simplified versions (fig. 3), useful for the descriptive and didactic point of view but never used by the philosopher.
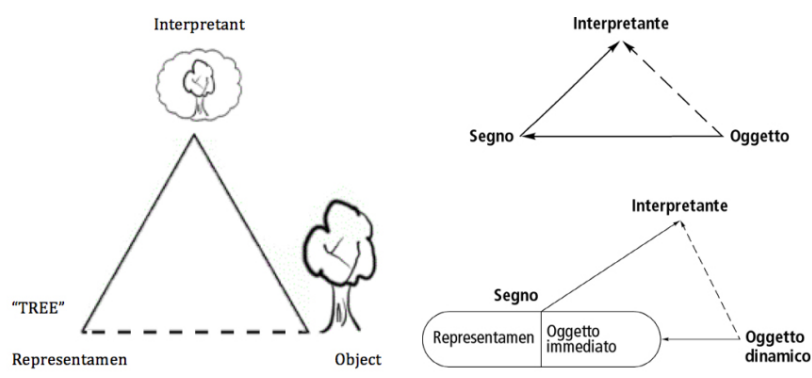

Fig. 3 - The canonical representation of the 'semiotic triangle' and two versions of it (Ogden \& Richards, 1966)

\footnotetext{
${ }^{4}$ Not all scholars still agree in distinguishing, into the concept of sign, 'representamen' and 'immediate object' and many prefer to use the term 'object' instead of 'sign'. This also depends on the difficulty in reading Peirce's work, rarely elaborated in organic form and with frequent re-thinking by the author (see Fig. 3).
} 
The focus on specific topics such as 'pragmatic maxim', 'Theory of sign' and 'abductive reasoning' as well as the crystallization of the complex concept of 'semiosis' in the 'semiotic triangle' highlighted some aspects from the point of view of 'savoir savant'.

The different declinations of Pierce's thought - which spans across different areas such as logic, mathematics, psychology, metaphysics, etc. - and the not organic nature of his fragmentary and only partly organized works, lead scholars to often use organization criteria 'a posteriori' - such as, thematic or historical-biographical criteria. This allows to manage the huge amount of work, to create bases for intersubjective agreements between scholars and to develop a reduced savoir savant that is redefined over the time.

The stylistic and semantic difficulty linked to certain concepts - i.e. 'semiosis' - leads to the use explanatory simplifications that most often represents the scholar's interpretation and not the actual meaning expressed in Peirce's texts. Such a substantial intervention of scholars in defining the savoir savant could be characteristic of those philosophers whose work is not easy to read and remain subject for specialized studies and not for public domain. In this regard, the session organized by J. Campbell and R. Hart and supported by the AATP (American Association of Philosophy Teachers) in 2007 on the occasion of the SAAP (Society for the Advancement of American Philosophy) hosted 14 scholars on their experience in the 'teaching of Peirce to university students in a variety of courses (Campbell, Hart, de Waal, 2007). Their point of view was not the content (Peirce) but the most effective way of letting it be learned by the different types of students ${ }^{5}$.

\section{Methodology}

The study has been mainly inspired by the L. Shulman's theoretical model of Pedagogical Content Knowledge (PCK) (Shulman, 1986; 1987) and the construct of 'didactic transposition' (Develay, 1992, 2015); it extends the results of a previous study that addressed the process of integration/transformation from the second internal transposition level (savoir enseignés - see fig. 2) of a Philosophy subject matter - the Italian philosopher G.B. Vico (Agrati, 2019).

The present study has been driven by two research questions:

- what topics of Peirce's thought can be found in textbooks (meanings, relation with, location etc.)?

- which texts/graphic organizers are used to explain the topics (metaphors, examples, graphs etc.)?

It aimed at detect the main topics of C.S. Peirce, available in school textbooks, and how these are explained by the texts/ graphic organizers - in this way, it intended to describe the first external transposition level of the school mediation and, specifically, describe the work of transforming a philosophical savoir savant ('scholarly knowledge' = some Peirce's main topics) in a savoirs à enseigner ('knowledge to be taught' = Peirce's topic available in the school textbooks of Philosophy) ${ }^{6}$.

After a general presentation of the school textbook analysis method, the procedures followed and the chosen analysis criteria will be described.

\section{School textbook as object of analysis}

The textbooks are object of study ${ }^{7}$ and analysis since 1988 when UNESCO coordinated the first investigation (Hummer, 1988) that allowed to defined them, at an international and interdisciplinary level, as 'didactic sources and tools' and trough some analytical characteristics (p. 24):

Format-'size, use of colour, typeface, lay-out, binding';

Presentation-'sequencing and structuring of material, factual content, variety in presentation, case study, crossreferences';

\footnotetext{
${ }^{5}$ Through class discussions (J. Campbell), connections with other philosophers - Dewey (V. Colapietro) or Cartesio (de Waal, Legg), reflections on the order of complexity within American history (H. de Regt), focus on semiotics (L.A. Mc Bride) or on the theory of learning (K. Hull).

${ }^{6}$ See also the explanatory model used by Valverde et al. (2002) which instead distinguishes intended (formed by the educational system and national policy), potentially implemented (realized through textbooks and other organized tools) and implemented (actually produced in teaching practice) curriculum.

${ }^{7}$ Since the transposition of Peirce's thought, done by the publishers/authors of the philosophy school text-books is the real object of the investigation, the school textbook is to be understood more as a means than as an object of analysis in this comparative study.
} 


\begin{abstract}
Language-'relation to target group, clarity, application of knowledge, definition, glossary';
Methodology - 'fostering of critical thinking and problem-solving skills; use of various sources and methods';

Achievement-'self-direction techniques, self-assessment, self-awareness'.
\end{abstract}

These basic features allow to analyze the different functions of the school book: favor the pleasure of reading; "to present the knowledge to be acquired (...) in a structured manner adapted to the level of his intellectual development' (Hummer, 1988, p. 18); transmits values and encourage attitudes in readers through 'hidden messages' contained in a textbook.

The investigations of E.L. Chiappetta (1991, 1993), on school textbooks of Science, in particular, provided qualitative and quantitative methods useful for analyzing the relationship between the contents and the school curriculum as well as the representation of the discipline provided.

Recent studies (O'Keeffe, 2013) highlighted the textbook as 'important vehicles for the promotion of curricula' (p. 1) and providesframework for textbook analysis (Morgan 2004, the TIMSS study - Valverde et al., 2002, Rivers 1990) which comprises four key elements: Content, Structure, Expectation, Language. Although analysis criteria refer mainly to the effectiveness of students' learning, content and structure features are highlighted as 'very important for the promotion of a specific vision of curriculum' (p. 1) or a specific 'surrogate' of it (Valverde et al., 2002).

- Content - Rivers's content analysis (1990) focused on 'Philosophical Position' (emphasis and predominant philosophy), that of Robinson (1981) focuses instead on presenting the message clearly and comprehensibly.

- Structure - sequence and connections between the elements of the text are carefully analyzed by Mikk (2000, p. 99) - schematically record the frequency with which ideas/arguments appear and then the connections are displayed. The analysis carried out followed the criteria related to the subject presented (see Content), not to the graphic aspect (as the 'physical scale' of the TIMSS report that refers to pictorial elements, color and non-color, etc.).

- Language - Mulryan (1984) provides some subheadings for language analysis as:

○ word signifiers - 'General vocabulary: word signs used regularly in daily life e.g. and, from'; discipline's terms: 'term with specific disciplinary meaning, there are two types technical or special'; Technical vocabulary: word signs peculiar to discipline(e.g. 'metaphysic'); 'Special vocabulary: word signs used in daily life which have different mathematical meaning e.g. match, set, group or figure';

O graphical signs - 'Pictorial/diagrams symbols: pictures/graphs which demonstrate discipline's principles'.

The synthesis of the studies on the analysis criteria provided by Lebrun, Lenoir and Laforest (2002) for primary school textbooks and some other studies link with the school curriculum (You, Lee \& Craig, 2018) are to be recalled.

\title{
Method of analysis
}

The textbook analysis (O'Keeffe, 2013; Chiappetta et al., 1993) was carried out through a comparison of two school textbooks of Philosophy, the most widespread in the Italian High schools: ST1 (Reale \& Antiseri, 1997), ST2 (Abbagnano \& Fornero, 2013) ${ }^{8}$. The index of entire textbook and the sections related to the American philosopher have been analyzed using 'ad hoc' criteria - content (selection of topics and prevailing links), structure (sequence and articulation of topicswithin the whole work) and language (meaning of terms and technical vocabulary) - O'Keefe (2013), Valverde at al. (2002), Rivers (1990), Mikk (2000), Mulryan (1984).

Tab. 3 - Summary table for thetextbook analysis

\begin{tabular}{lll}
\hline Criteria & ST1 & ST2 \\
\hline Content - topics' selection and prevailing links & & \\
Structure - topics' location within the textbook & & \\
Language - meaning of terms, vocabulary (v. definition, glossary etc.) & & \\
\hline
\end{tabular}

\footnotetext{
${ }^{8}$ These are extended and updated editions: 'Reale\&Antiseri' $1^{\text {st }}$ edition was in 1983 , the $19^{\text {th }}$ edition of 1997 is the one analyzed; 'Abbagnano \& Fornero' $1^{\text {st }}$ edition is of 1986 , the $9^{\text {th }}$ edition of 2013 has been analyzed.
} 


\section{Analysis of data}

The textbook analysis procedure followed three phases: the first one found the main topics within the paragraphs (Content), the second detected the references to Peirce found in other chapters (Structure), the third performed the comparison using the summary table (see Tab. 3) and focused on the linguistic aspects. A first descriptive and then synthetic analysis of the textbook are presented.

School-text 1 (Reale \& Antiseri, 1997) ${ }^{9}$

A thematic paragraph of 6 pages is dedicated to Peirce ('The logic pragmatism of C.S. Peirce') within Chapter 16 'The Pragmatism'. After an introductory paragraph on Pragmatism, Peirce's thought is divided into 6 sub-paragraphs (Tab. 5):

Tab. 5 - Content of Peirce as 'Philosophical content knowledge' (Reale \& Antiseri, 1997)

\begin{tabular}{|c|c|}
\hline Title of paragraphs & Topic \\
\hline \multirow{2}{*}{$\begin{array}{l}\text { 2.1 Procedures for setting } \\
\text { 'beliefs' }\end{array}$} & - knowledge as research that leads from doubt to belief \\
\hline & - 4 methods of investigation (tenacity, authority, a priori, scientific) the last of which is preferred \\
\hline \multirow{2}{*}{$\begin{array}{l}2.2 \text { Deduction, induction, } \\
\text { abduction }\end{array}$} & -3 basic forms of reasoning \\
\hline & - abduction's explicative scheme (p. 376). \\
\hline \multirow{2}{*}{$\begin{array}{l}2.3 \text { How to make our ideas } \\
\text { clear: the pragmatic maxim }\end{array}$} & - quote from the pragmatic maxim (see Par. 1.2) \\
\hline & - belief as a possible rule of action and truth 'in fieri' \\
\hline \multirow{2}{*}{ 2.4 Semiotics } & - logical and non-communicative sense of semiotics (see Morris interpretation) \\
\hline & - triadic nature of the sign and difference between Icon, Index, Symbol \\
\hline \multirow[b]{2}{*}{ 2.5 Phaneroscopy } & - investigation of the essential characteristics of phenomenon (phaneron) \\
\hline & $\begin{array}{l}\text { - three categories of 'Firstness' (being independent of anything else), 'Secondness' (existence } \\
\text { as being 'in relation to'), 'Thirdness' (the kingdom of law or habit, the recognized link between } \\
\text { things and concepts) }\end{array}$ \\
\hline \multirow{4}{*}{ 2.6 Cosmology } & - difference between tichism, sinechism, agapism \\
\hline & - application of the triadic scheme on the cosmological level \\
\hline & $\begin{array}{l}\text { - 'all things tend to acquire habits' - from indeterminism (case - tichism), to the first relations } \\
\text { (continuous - sinechism), to the generative ties (love - agapism) }\end{array}$ \\
\hline & - tendency inherent in the universe in evolutionary function \\
\hline
\end{tabular}

Other references to Peirce are in n. 16/855 pages of 3/49 chapters (Tab. 6)

Tab. 6 - Structure of Peirce as 'Philosophical content knowledge' (Reale \& Antiseri, 1997)

\begin{tabular}{lll}
\hline Chapter & Paragraph & Topic \\
\hline $\begin{array}{l}\text { 9. 'The sciences } \\
\text { development in } 19^{\text {th }}\end{array}$ & $\begin{array}{l}\text { 'The mathematical reorganization } \\
\text { process' (p. 275) }\end{array}$ & \\
16. 'Pragmatism' & $\begin{array}{l}\text { 'The truth of an idea is reduced to its } \\
\text { ability to operate' }\end{array}$ & $\begin{array}{l}\text { difference between W. James's pragmatism and Peirce's } \\
\text { pragmaticism (p. 380) }\end{array}$ \\
& $\begin{array}{l}\text { 'The principles of psychology and the } \\
\text { mind as an adaptation tool' }\end{array}$ & $\begin{array}{l}\text { mistaken psychological interpretation of Peirce's } \\
\text { pragmatism made by James (p. 381) }\end{array}$ \\
& 'Pragmatism in Italy' & $\begin{array}{l}\text { attempt to revisit James's erroneous psychological } \\
\text { interpretation of Peirce's pragmatism by Calderoni and } \\
\text { Vailati (pp. 385-6) }\end{array}$ \\
\hline
\end{tabular}

\footnotetext{
${ }^{9}$ The textual analysis does not include the exergo of the eighth part of the text 'Philosophy from $18^{\text {th }}$ to $19^{\text {th }}$ Century' which reports Peirce's definition 'A hypothesis is, for a scientific mind, always a proof' (Reale \& Antiseri, 1997, p. 323).
} 
Tab. 6 cont.

\begin{tabular}{lll}
\hline Chapter & Paragraph & Topic \\
\hline $\begin{array}{l}\text { 46. 'Great protagonists of } \\
\text { contemporary American } \\
\text { philosophy' }\end{array}$ & $\begin{array}{l}\text { Lewis' } \\
\text { 'Criticism of reductionism and } \\
\text { proposal of methodological holism' } \\
\text { (W.V.O. Quine) }\end{array}$ & Peirce' influence (p. 802) \\
'The three dimensions of semiotics: \\
$\begin{array}{l}\text { syntactic, semantic, pragmatic' } \\
\text { (C. Morris) } \\
\text { 'The idealistic pragmatism of N. } \\
\text { Rescherin' }\end{array}$
\end{tabular}

School-text 2 (Abbagnano \& Fornero, 2013)

A 2-page paragraph is dedicated to Peirce ('Peirce') within Chapter 2 'Pragmatism', in Unit 5 'Spirit and action: neoidealism and pragmatism'. After a very brief introduction in which Peirce is defined 'founder of pragmatism' ( $\mathrm{p}$. 263), his thought is articulated in 2 sub-paragraphs:

Tab. 7 - Content of Peirce as 'Philosophical content knowledge' (Abbagnano \& Fornero, 2013)

\begin{tabular}{|c|c|}
\hline Paragraphs & Topic \\
\hline \multirow[t]{4}{*}{ 'Method of the reason' } & - quote from the pragmatic maxim (see Par. 1.2) \\
\hline & - knowledge as production of belief, rule of action \\
\hline & $\begin{array}{l}\text { - } 4 \text { methods to develop a belief: three illegitimate (tenacity, authority, a priori - the } \\
\text { possibility of error is excluded, p. 263), one legitimate (scientific - the results are } \\
\text { constantly correctable) }\end{array}$ \\
\hline & $\begin{array}{l}\text { - ontological-metaphysical effects of the assumption }=\text { all kinds of necessities and } \\
\text { immutable truths or beliefs are excluded }\end{array}$ \\
\hline \multirow[t]{7}{*}{ 'Abduction and semiotics' } & $\begin{array}{l}\text { - abduction as 'form of scientific reasoning', 'modality of reasoning', 'inferential chain } \\
\text { that allows passing from some known facts to the hypothetical position of a principle } \\
\text { that explains them' (p. 264) }\end{array}$ \\
\hline & - use of well-known examples of beans and wet road (p. 264). \\
\hline & - semiotics as 'discipline that deals with signs, their interpretation and their use' (p. 264) \\
\hline & - thought and universe made 'of signs' \\
\hline & $\begin{array}{l}\text { - relationship with reality is not direct but mediated by the signs that favors a 'continuous } \\
\text { interpretation' (infinite semiosis) based on those values shared by the community of } \\
\text { persons that preserve its public and interpersonal objectivity }\end{array}$ \\
\hline & - sign as 'something that for someone (interpretant) stands for something (object)' \\
\hline & $\begin{array}{l}\text { - these three elements refer to each other: 'the sign is such only if it is in the place of } \\
\text { something else (object), but it can perform its intrinsic function only if someone } \\
\text { (interpreted) understands it as such, that is to say in the place of something else. The } \\
\text { interpretant, for its part, is such because it has always moved within the sign universe' } \\
\text { (p. 265) }\end{array}$ \\
\hline
\end{tabular}

About the in-depth boxes that accompany the paragraph, that of belief and fallibility does not add new information, that of abduction contains a quote from Peirceand clarifies that the explanation given is not that necessary or the best. 
Additional references to Peirce are in n. 11/733 pages of 3/32 chapters (Tab. 8).

Tab. 8 - Structure of Peirce as 'Philosophical content knowledge' (Abbagnano \& Fornero, 2013)

\begin{tabular}{|c|c|c|c|}
\hline Unit & Chapter & Paragraph & Topic \\
\hline \multirow[t]{3}{*}{$\begin{array}{l}\text { 5. 'Spirit and action: } \\
\text { neoidealism and } \\
\text { pragmatism' }\end{array}$} & 2. 'Pragmatism' & 1. 'General characteristics' & $\begin{array}{l}\text { difference between methodological (Peirce and Dewey) } \\
\text { and metaphysical (James) pragmatism (p. 262) }\end{array}$ \\
\hline & & 4. 'Dewey' & $\begin{array}{l}\text { reaffirmation of the Peircian concept of fallibility by } \\
\text { Dewey (p. 274) }\end{array}$ \\
\hline & & $\begin{array}{l}\text { summary map of the chapter } \\
\text { (p. 275) (fig. 4) }\end{array}$ & \\
\hline $\begin{array}{l}\text { 8. 'Philosophy and } \\
\text { science' }\end{array}$ & $\begin{array}{l}\text { 1. 'Frege, Russell } \\
\text { and neopositivism' }\end{array}$ & $\begin{array}{l}\text { 3. 'The neo-positivism: } \\
\text { general traits' }\end{array}$ & $\begin{array}{l}\text { the debt of W.V.O. Quine and E. Nagel towards Peirce } \\
\text { and Dewey (p. 435) }\end{array}$ \\
\hline \multirow[t]{4}{*}{$\begin{array}{l}\text { 11. 'Between modern } \\
\text { and post-modern' }\end{array}$} & $\begin{array}{l}\text { 1. 'The defense } \\
\text { of modernity: }\end{array}$ & 3. 'Apel' & $\begin{array}{l}\text { Peircian influences in the linguistic-communicative } \\
\text { approach of the Apel's philosophy (pp. 660), }\end{array}$ \\
\hline & $\begin{array}{l}\text { Habermas and } \\
\text { Apel' }\end{array}$ & & $\begin{array}{l}\text { Peircean heritage in the 'analytic' current of Anglo- } \\
\text { American philosophy (p. 661) }\end{array}$ \\
\hline & & & $\begin{array}{l}\text { Peircian heritage in the concept of 'ideal community' } \\
\text { that is 'able to act as a normative reference and } \\
\text { matrix of the interpretations of the real subjects of the } \\
\text { historical community' (p. 662) }\end{array}$ \\
\hline & $\begin{array}{l}\text { 2. "The postmodern } \\
\text { theorists" }\end{array}$ & $\begin{array}{l}\text { 4. 'Rorty: the philosophy of } \\
\text { conversation' }\end{array}$ & $\begin{array}{l}\text { reaffirmation in a logical sense of Peirce's pragmatic } \\
\text { maxim in Rorty's early works (p. } 677 \text { ) }\end{array}$ \\
\hline
\end{tabular}

From the comparison of the data in the tabs. 5 and 7 (Content criteria), of the tabs. 6 and 8 (Structure criteria) it is possible to obtain the following summary table (tab. 9):

Tab. 9 -Summary table of the comparative analysis on content and structure

\begin{tabular}{lll}
\hline Criteria & ST1 & ST2
\end{tabular}

Content - selection of topics and prevailing links

Structure - sequence and articulation (= location) of topicswithin the whole textbook

Language - meaning of terms and technical vocabulary referring the topics - definition, glossaryetz.
Beliefs > Investigation

Abduction $>$ third form of reasoning

Pragmatic maxim $>$ Beliefs and truth

Semiotics $>$ Icon, Index, Symbol

Phaneroscopy $>$ Firstness, Secondness, Thirdness

Cosmology > tichism, sinechism, agapism

- $19^{\text {th }}$ Century mathematical reorganization

- difference between James's and Peirce's pragmatism

- influence of Peirce on Italian pragmatism

- fundamental influence of Peirce on American philosophy (Lewis, Quine, Morris, Rescherin, Putman)

Abduction > explicative scheme use of Peirce's original words ('neologisms'), even if difficult to understand
Reasoning $>$ belief and scientific procedure $>$ exclusion of all kinds of necessities

Abduction $>$ scientific investigation method Semiotics $>$ sign / interpretant / object $>$ infinite semiosis

- similarity between Dewey's and Peirce's pragmatism

- difference between James's and Peirce's pragmatism

- influence of Peirce on neo-positivism ( Quine), practical philosophy (Apel) and postmodern thought (Rorty)

Abduction $>$ explanatory metaphors

Sentencessimplifying the complex meanings and oftenwithout direct reference to the author's terms (see fig. 4). 


\section{Results}

Firstresearch question - what topics of Peirce's thought can be found in school textbooks?

From point of view of the content, the summary table (Tab. 9) shows that in ST1 (Reale \& Antiseri, 1997) there are more topics of Peirce's thought with respect to ST2 (Abbagnano \& Fornero, 2013) - see Criteria.

In ST1 there are not only the canonical concepts of belief, abduction and semiotics - linked tothe 'core' concept' of pragmatism - but also the complex ontological-metaphysical concepts of phaneroscopy and cosmology - related to Firstness, Secondness, Thirdness, tichism, sinechism, agapism. A specific paragraph is dedicated to each of them. The authors do not operate syntheses between them and tend rather to make explicit the complexity of Peirce's thinking by adding the metaphysical-ontological component to the logical-cognitive one.

ST2 mainly focuses on scientific research (directly associated with abduction and the new concept of world-chaos) and on the semiotic process that distinguishes sign, interpretant and object. The authors tend to redirect Peirce's thought to two main focuses (scientific investigation and semiotics) and to emphasize only the cognitive-scientific component.

Moreover, while ST1 assumes the pragmatism as a significant center of discourse, placing the pragmatic maxim at the center, ST2 instead chooses the concept of belief to which it associates the argument on scientific investigation.

From the structure point of view, the summary table (Tab. 9) shows that ST1 associates Peirce's thought mainly with the different components of pragmatism: that original of James, the Italian and, above all, American. St2 instead offers a more composite and updated picture of the American philosopher's influence - in the pragmatism of Dewey and James but also in neo-positivism, in practical philosophy and in postmodern thought.

Second research question - which texts/graphic organizers are used to explain the contents?

From the content point of view, the summary table (Tab. 9) shows that in ST1 (Reale \& Antiseri, 1997) authors mainly use of Peirce's original words ('neologisms'), even if difficult to understand. An example is the passage that describes the triadic structure on a cognitive-logical and metaphysical level: 'Considered for itself, a sign can be: 1) Qualisign (e.g. color perception), 2) Signsign (e.g. any object), 3) Legisign (e.g. convention). Considered in relation to its object, a sign can be: 1) Icon (e.g. drawing or diagram), 2) Index (e.g. signal), 3) Symbol (e.g. cultural product). Considered in relation to the interpretant, the sign can be: 1) Rheme (e.g. proposition 'x is yellow'), 2) Dicisign (e.g. object or event indicating a quality, 'the rose is yellow'), 3) Argument (e.g. inferential chain of at least three dicisingns, 'the syllogism')' (Raele \& Antiseri, 1997, p. 377).

The authors do not resort to the well-known and explanatory semiotic table; they use a long period that is difficult to understand but respectful of the author's thought and original words.

ST2's authors, instead, resort to sentences simplifying the complex meanings and often without direct reference to the Pearce's original terms (see fig. 4).

Observing the only graphic organizer (Bonaiuti, 2011), found in the ST2 (fig. 4) that represents Peirce's pragmatism, it is possible to note that are highlighted only the concepts of belief, linked toscientific fallibility, and of scientific investigation, correspondingto abduction. The matching of scientific investigation and abductive reasoning would seem to be a reduction of the author's meanings and the statement that, according to Peirce, chaos is a feature of the world is misleading.
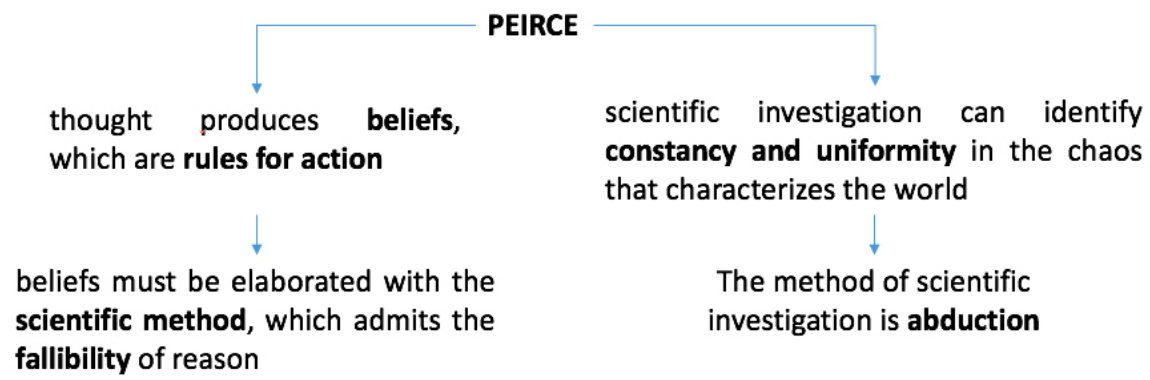

Fig. 4 - Graphic organizer of Peirce's pragmatism (Abbagnano \& Fornero, 2013, p. 275) 
This last interpretation is linked to another sentence where the term 'case' has been used: 'World is the kingdom of case: a case, however, in which constancy or uniformity of events can be found, which constitute the object of scientific investigation and are expressed by the laws formulated by science' (Abbagnano \& Fornero, 2013, p. 264). This interpretation of the world as case/caoscould be quite reductivegiven that Peirce's thought admits the existence of reality, although not knowable (Maddalena, 2015).

Another aspect distinguishes the textbooks. The authors of ST1 use the logical explanatory scheme to explain abductivereasoning - 1 - C is observed, a surprising fact; 2 - But if A were true, then $C$ would be natural; 3 - There is, therefore, reason to suspect that $A$ is true (Reale \& Antiseri, 1997, p. 376). The authors of the ST2, instead, resort to the well known metaphors of the 'beans' and to the simpler 'wet road': 'all the beans in this bag are white; these beans are white; these beans come from this bag'; 'if you imagine waking up one morning to find the wet road, you can assume that during the night it rained' (Abbagnano \& Fornero, 2013, p. 264).

It should be noted that the two textbooks do not uses the table that distinguishes the three reasoning - deduction, induction, hypothesis (Tab. 2) and the well-known semiotic triangle to describe the sign-object-interpretant semiotics (fig. $3)$. It is now known that it is a non-original representation and that its actual configuration is still debated.

\section{Implications}

On the level of textbook analysis, the results offer useful information to investigate that hidden message, already explained by Hummer in the UNESCO survey (Hummer, 1988, p. 22). In particular, the method used,inspired by Rivers (1990) and focused on 'philosophical position' (emphasis and predominant philosophy), brought out the different readings/interpretations that the authors of school textbooks offer about the same Peirce's topics - e.g. 'abduction' as type of reasoning (ST1) or main scientific procedure (ST2); 'triadic scheme' applicable to all the planes of reality (ST1) or mainly to the logic of the scientific investigation (ST2) - and, consequently, to his thought.

The results offer indications regarding Peirce's thought as 'knowledge to be taught' (Develay, 2015) and 'subject matter content knowledge' (Shulman, 1986; Schwab, 1978) at the external phase of the didactic transposition (Fig. 2). It has been noticed that though the Italian Syllabo of Phylosophia (Tab. 1) does not contain Peirce neither as a mandatory content knowledge nor a choice, however, it is a philosopher constantly present in the main school textbooks. The criterion of the structure followed for the analysis has brought out even better the different interpretations - more or less up to date of Peirce's thought offered by the authors of textbooks - as a full pragmatist (ST1) or a forerunner of postmodern thought (ST2).

The interpretation realized by the textbooks' authors on the philosopher's concepts - e.g. world as the 'kingdom of chaos' (ST2) - for reasons of synthesis or effective intervention in meanings - is a specific aspect of 'knowledge to be taught'and it should be deepened with further studies.

From a methodological point of view, the criteria offered by the literature - derived from studies on school textbooks mainly of mathematical and scientific disciplines and, in any case, useful for the present study -remains to be integrated with possible further criteria related to the textbooks of Philosophy in High Schools. These findings will be useful to the operational definition of the 'unit of analysis' in subsequent study to be conducted on a broader basis.

\section{Conclusions}

The present study contributes to expand the explanatory model of mediation - that is focused on the integration between teachers (T), students (S), cultural object (Co), system of devices (Md) (Fig. 1, Damiano, 2013; Cochran, 1997) within the class - through the investigation of the production process of the 'cultural object' - well explained by the descriptive model of the 'didactic transposition' (Chevallard, 1991; Develay, 1992, 2015; Waquet, 2015) - focused farther on the relation between scholars, program designers, authors of school textbooks, which precedes classroom work.

Two main aspects are highlighted in conclusion: the first relating to the textbook as a 'mediator' of the school curriculum; the second refers to Peirce as 'knowledge to be taught' (savoir à enseigner).

We know especially today that 'in contemporary education, the school textbook is no longer the only didactic tool, but forms part of a resource of learning materials' (Hummer, 1988, p. 21).

The textbook is an artifact (Matic \& Gracin, 2016) that nevertheless affects the contents of the curriculum especially for the humanities disciplines: the selection and presentation of the contents unavoidably influences the knowledge to be 
taught and to be learned. In this respect, teachers should read the adopted textbook more critically and perhaps integrate it through additional learning tools (e.g. authors' original books, personal researches) in order to be effective 'mediators' between knowledge and students.

Many analysis of school book use efficacy criteria regarding student learning (motivation, effectiveness in checking outcomes); it would be appropriate to address the analyzes also on the translation from 'scholarly knowledge' to 'knowledge to be taught' to bring out the integrations with respect to the school curriculum and the importance of the teachers' work.

Shulman's model of PCK $(1986,1987)$ is useful to describe teaching-learning processes, however, the model of didactic transposition helps to better understand the phase that precedes the work in the classrooms because, from a theoretical point of view, it considers the adaptation of the specialized knowledge in 'knowledge to be taught'.

It has been highlighted, in fact, that Peirce as 'knowledge to be taught' is only sometimes comparable to the so complex and sometimes 'mysterious' Pierce of the scholars. This is natural within the teaching-learning process but teachers and students should be aware of this and be able to choose accordingly.

\section{References}

Abbagnano N., Fornero G. (2013). L'ideale e ilreale. Corso di Storiadellafilosofia. Vol. 3. Da Schopenhauer aglisviluppipiùrecenti. Paravia - Pearson.

Altet M. (1997). Les pédagogies de l'apprentissage. Paris: PUF.

Anderson S. (2007). Finding Peirce's World. In Campbell J., De Waal C., Hart R. (2007) (eds). Teaching Peirce to Undergraduates. In https://philarchive.org/archive/CAMTPT-7

Agrati L. (2019). The mediate (zati) on of Philosophy subject matter. A comparative case study. In Mena J., GarcíaValcárcel A., García Peñalvo F. (eds.), Teaching search and research: conceptualizations of the school practices. SENSE Publishing.

Ball, D. L., Thames, M. H., \& Phelps, G. (2008). Content knowl- edge for teaching: What makes it special? Journal of Teacher Education, 59, 389-407. doi:10.1177/0022487108324554

Benadusi L., Censi A., Fabretti V. (2004). Lineamenti di sociologiadell'educazione. Milano: FrancoAngeli.

Bergman M. (2004). Fields of Signification. Explorations in Charles S. Peirce's Theory of Signs. Department of Philosophy, Department of Social and Moral Philosophy, University of Helsinki. Finland

Bonaiuti, G. (2011). Organizzatori grafici e apprendimento. In A. Calvani. Principi di comunicazione visiva e multimediale. Fare didattica con le immagini. Roma: Carocci.

Bonfantini M. (2003). Introduzione. In Peirce C.S., Opere (a cura di M. Bonfantini). Milano: Bonpiani.

Chiappetta E. L., Fillman D.A., Sethna GH (1991). A method to quantify major themes of scientificliteracy in science textbooks. Journal of Research in Science Teaching, 28(8), 713-725.

Chiappetta E. L., Sethna G. H., Fillman D. A. (1993). Do middle school life science textbooksprovide a balance of scientificliteracythemes? Journal of Research in Science Teaching, 30(7), 787-797.

Chevallard Y. (1991). La transposition didactique: du savoir savant au savoir enseignè. Grenoble: La PenséeSauvage.

Clément P. (2007). Introducing the cell concept with both animal and plant cells: a historical and didactic approach. Science \& Education, 16, 423-440.

Cochran K. (1997). Pedagogical Content Knowledge: Teachers' Integration of Subject Matter, Pedagogy, Students, and Learning Environments, Research Matters to the Science Teacher, 9702, Jan. 14.

Damiano E. (2013), La mediazione didattica. Per una teoria dell'insegnamento. Milano: FrancoAngeli.

Develay M. (1992). De l'apprentissage à l'eneignement. Paris: ESF.

Develay M. (2015). La logique d'un programme de connaissances. In M. Develay. D’un programme de connaissances à un curriculum de compétences. Bruxelles: De Boeck. 
Eco U. (1984). Semiotica e filosofia del linguaggio. Torino: Einaudi.

Fadda E. (2013), Peirce. Roma: Carocci.

Ferrari, F. (2017). Philosophy in Schools [Review of the book: Philosophy in Schools, by F. Haynes]. Italian Journal of Sociology of Education, 9(1), 219-224.

Haynes F. (2016). Philosophy in Schools. London: Routledge.

Johnasen J.D., Larsen S.E. (2002). Signs in use. An introduction to semiotics. London: Routledge.

Kang W., Kilpatric J. (1992). Didactic Transposition in Mathematics textbooks. FLM Publishing Association, White Rock, Columbia: Canada.

Lebrun J., Lenoir Y., Laforest M. (2002). Past and Current Trends in the Analysis of Textbooks in a Quebec Context. Curriculum Inquiry. 32(1): 51-83.

Lévi-Strauss C. (1949). Les structures élémentaires de la parenté. Paris: Presses universitaires de France.

Maddalena, G. (2015). Peirce. Brescia: La Scuola.

Manetti G. (1987). Le teorie del segno nell'antichità classica. Milano: Bompiani.

Matic L., Gracin D.J. (2016). The use of the textbookas an artefact in the classroom. Journal für Mathematik - Didaktik, 37(2), 349-374.

Mikk J., (2000). Textbook: Research and Writing. Oxford: Lang.

Morgan, C., (1995), An Analysis of the Discourse of Written Reports of Investigative Work in GCSE Mathematics, Unpublished, University of London.

Morgan, D.E. and Perry, C. (1958). The teaching of philosophy in American High Schools. Proceedings and Addresses of the American Philosophical Association, 32 (1958-1959), 91-137.

Mulryan, C. (1984). Effective communication of mathematics at primary level: Focus on the textbooks. Irish Educational Studies, 4 (2).

O'Keefe L. (2013). A Framework for Textbook Analysis. International Review of Contemporary Learning Research. Vol. 1, pp. 1-13.

Ogden C., Richards I. (1966). Il significato del significato. Trad. it., Milano: Saggiatore.

Peirce C.S. (1931-58). The CollectedPapers of Charles SandersPeirce. 8 vols. Charles Hartshorne, Paul Weiss and Arthur Burks (eds). Cambridge: Harvard University Press.

Peirce C.S. (1992-98). The Essential Peirce: Selected Philosophical Writings. 2 vols. Nathan Houser, Christian Kloesel, Peirce Edition Project (eds). Bloomington: Indiana University Press.

Reale G., Antiseri D. (1997). Il pensiero occidentale dalle origini ad oggi. XVIII edizione. Brescia: La Scuola.

Rivers, J., (1990), Contextual Analysis of Problems in Algebra 1 Textbooks, University of South Carolina, Presented at the annual meeting of the American Educational Research Association, April, Boston, Massachusetts.

Robinson, J. (1981). Research in Science Education: New Questions, New Directions. National Centre of Education, Educational Resources Information Centre.

Rossi P.G., Pizzimenti L. (2012). La trasposizione didattica. In P.C. Rivoltella, P.G. Rossi (2012). L'agire didattico. Manuale per l'insegnante (pp. 167-184). Brescia: La

Schubauer-Leoni M.L. Leutenegger F. (2002), Expliquer et comprendredansuneap- procheclinique/expérimentale du didactiqueordinaire. In F. Leutenegger, M. Saada-Robert (eds.), Expliquer et comprendre en sciences de l'éducation (pp. 227-251). Bruxelles: De Boeck. Scuola.

Schwab J.J. (1978). Science, Curriculum and Liberal Education: Selected Essay. Chicago: University of Chicago Press. Shulman L. (1986). Those who understand: Knowledge growth in teaching. Educational Researcher, 15(2), 4-14. 
Shulman L. S. (1987). Knowledge and teaching: Foundations of the new reform. Harvard Educational Review, 57(1), $1-22$.

Simmons S. (2011). Philosophical dimensions of drawing instruction. In A.

Kantrowitz, A. Brew, M. Fava (eds.) (2011), Thinking through drawing: practice into knowledge. Proceedings of an interdisciplinary symposium on drawing, cognition and education (pp. 39-44). New York: Teachers College, Columbia University, Art and Art Education, Bobek Edition.

UNESCO (2007). Philosophy. A school of freedom. Paris: UNESCO.

UNESCO (2009). Teaching philosophy in Europe and North America. Paris: UNESCO.

UNESCO (2015). Global Citizenship Education. Paris: UNESCO.

UNESCO (2017). Education transforms lives. Paris: UNESCO.

Valverde G., Bianchi L., Wolfe R., Schmidt W. Houang R. (2002). According to the Book: Using TIMSS to Investigate the Translation of Policy Into Practice through the World of Textbooks. London: Kluwer Academic Publishers.

Vaz L.M. (2017). The Didactic Transposition in Brazilian High School Physics Textbooks: A Comparative Study of Didactic Materials. International Journal of Educational and Pedagogical Sciences. Vol:11, No:4.

Vygotsky L. S. (1934/1962). Thought and Language. Boston: MIT Press.

Waquet F. (2015). L'ordre matériel du savoir. Comment les savants travaillent (xvie-xxie siècles). Paris: Editions du CNRS.

Xypas C., Fabre M., Hétier R. (dir.) (2011). Le tiers éducatif. Une nouvelle relation pédagogique. Figures et fonctionsdutiers en éducation et formation. Bruxelles: De Boeck.

You J., Lee H., Craig C. J. (2019). Remaking Textbook Policy: Analysis of National Curriculum Alignment in Korean School Textbooks. Asia Pacific Journal of Education, 39(1), 14-30. 